\title{
PENGGUNAAN KAPPA-KARAGINAN SEBAGAI BAHAN PENSTABIL PADA PEMBUATAN FISH MEAT LOAF DARI IKAN TONGKOL (Euthyinnus pelamys. $L$ )
}

\author{
Th. Dwi Suryaningrum"), Murdinah"), M. Arifin")
}

\begin{abstract}
ABSTRAK
Masalah yang timbul dalam pembuatan produk emulsi seperti fish meat loaf adalah pecahnya sistem emulsi. Pada penelitian ini dipelajari penggunaan kappa-karaginan sebagai bahan penstabil dan pengaruhnya terhadap sistem emulsi produk yang dihasilkan. Penelitian dilakukan untuk melihat pengaruh konsentrasi $k$-karaginan $(0 \%$, $0,25 \%, 0,50 \%, 0,75 \%, 1 \%)$ serta lama waktu penyimpanan $(0,15,30,45$ dan 60 hari) terhadap sifat emulsi produk (protein larut garam, daya ikat air, aktivitas emulsi, stabilitas emulsi), komposisi proksimat, jumlah bakteri total, pH dan mutu organoleptiknya (warna, bau, rupa, rasa serta tekstur). Hasil penelitian menunjukkan bahwa penggunaan $k$ karaginan memberikan pengaruh terhadap peningkatan kadar air, protein, lemak, abu, protein larut garam, daya ikat air, aktivitas emulsi, stabilitas emulsi dan $\mathrm{pH}$. Sedangkan lama penyimpanan menyebabkan peningkatan daya ikat air, $\mathrm{pH}$, jumlah bakteri total, serta menurunnya kadar protein, lemak, protein larut garam, aktivitas emulsi, stabilitas emulsi, dan semua parameter organoleptik yang diamati. Penggunaan $k$-karaginan dengan konsentrasi $1 \%$ menghasilkan sifat emulsi produk terbaik dibandingkan dengan konsentrasi $k$-karaginan lainnya. Sedangkan jika dihubungkan dengan penyimpanan maka penggunaan $k$-karaginan dengan konsentrasi $0.75 \%$ menghasilkan sistem emulsi produk yang lebih stabil bila dibandingkan dengan lainnya. Penggunaan $k$-karaginan dengan konsentrasi $0,75 \%$ dan $1 \%$ mampu mempertahankan sistem emulsi produk selama 30 hari, namun setelah 30 hari penyimpanan terjadi penurunan yang cukup cepat. Pengaruh konsentrasi $k$-karaginan terhadap sifat organoleptik, menyebabkan warna lebih cerah dan bau produk lebih harum dan berbeda nyata dengan kontrol. Penggunaan $k$-karaginan $0,75 \%$ menghasilkan cita rasa yang paling disukai oleh panelis.
\end{abstract}

\section{ABSTRACT: Use of Kappa Carrageenan as a Stabilizer in the Processing of Fish Meat Loaf from Little Tuna (Euthynnus pelamys L). By: Th. Dwi Suryaningrum, Murdinah and $M$. Arifin}

Problems occurred in the processing of emulsion products, such as fish meat loaf are the breaking up of emulsion system. Use of kappa-carrageenan as a stabilizing agent and its effects on the emulsion system of the products were investigated in this study. The study observed the effects of k-carrageenan concentration levels $(0.25,0.50,0.75$ and $1 \%)$ and storage periods $(0,15,3045$ and 60 days) on the emulsion properties including salt soluble protein content, water holding capacity, emulsion activity, emulsion stability, proximate composition, total bacterial count, $\mathrm{pH}$ and organoleptic acceptability (color, odor, appearance, taste and texture). Result indicated that the use of $k$ carrageenan showed a significant effect on the increase of moisture, fat, ash and salt soluble protein contents as well as water holding capacity, emulsion stability and $\mathrm{pH}$. Meanwhile, storage period induced the increase of water holding capacity, $\mathrm{pH}$ and total bacterial count as well as reduced protein, fat, salt soluble protein contents, emulsion activity, emulsion stability and all organoleptic scores. Use of $k$-carrageenan at $1 \%$ level resulted in product with the best emulsion characteristic compared to the other addition concentration levels. In relation to storage treatment, the addition of $0.75 \% \mathrm{k}$ carrageenan produced product with better emulsion stability than the other addition concentration levels. Uses of $k$-carrageenan at $0.75 \%$ and $1 \%$ addition levels were able to keep the emulsion characteristics for 30 days, but then reduced rapidly beyond that storage period. Products added with $k$-carrageenan had brighter color than the ones without $k$-carrageenan addition. The most acceptable taste product was produced with the addition of $0.75 \% k$-carrageenan .

\section{KEYWORDS: fish meat loaf, carrageenan, emulsion system.}

\footnotetext{
-. Peneliti pada Pusat Riset Pengolahan Produk dan Sosek Kelautan dan Perikanan

Mahasiswa pada Institut Pertanian Bogor
} 


\section{PENDAHULUAN}

Fish meat loaf merupakan suatu produk olahan daging ikan yang berbentuk emulsi minyak dalam air bercampur dengan protein myofibril. Produk ini merupakan campuran antara daging ikan, lemak, bahan pengikat dan bumbu-bumbu, yang sistem emulsinya mirip dengan sosis, sehingga faktor-faktor yang mempengaruhi proses pengolahannya juga mirip dengan sosis. Dalam pembuatan produk emulsi masalah yang sering timbul adalah tidak stabilnya sistem emulsi adonan. Hal ini akan mengakibatkan pecahnya sistem emulsi pada saat pengolahan dan penyimpanan. Agar sistem emulsi tersebut tidak pecah dan tahan lama diperlukan penambahan bahan penstabil. Penambahan bahan penstabil ini untuk mendorong terbentuknya ikatan kimia seperti ikatan garam, ikatan hidrogen, ikatan disulfida, dan interaksi hidrofobik yang berperan untuk membangun struktur jaringan tiga dimensi sehingga sifat emulsi produk dapat dipertahankan dan diperbaiki (Niwa, 1992). Dengan penambahan bahan penstabil ini, sistem emulsi pada produk akhir dapat dipertahankan. Penggunaan bahan penstabil selain bertujuan untuk mempertahankan sistem emulsi, juga dapat mempertahankan viskositas, tekstur, cita rasa dan memperpanjang masa simpannya (Winarno, 1991).

K-karaginan merupakan senyawa hidrokoloid yang diekstraksi dari rumput laut merah jenis Eucheuma cottonii. Menurut Glicksman (1983) k-karaginan dapat digunakan untuk meningkatkan kestabilan bahan pangan baik yang berbentuk suspensi (dispersi padatan dalam cairan), emulsi (dispersi cairan dalam cairan) maupun busa (dispersi gas dalam cairan). K-karaginan dapat digunakan sebagai bahan penstabil karena mengandung gugus sulfat yang bermuatan negatif di sepanjang rantai polimernya dan bersifat hidrofilik yang dapat mengikat air atau gugus hridroksil lainnya (Moirano, 1977). Karena sifatnya yang hidrofilik tersebut maka penambahan $k$ karaginan dalam produk emulsi akan meningkatkan viskositas fase kontinyu sehingga emulsi menjadi stabil (Frashier and Parker, 1985). Beberapa contoh penggunaan k-karaginan sebagai bahan penstabil antara lain untuk sardin kaleng sebesar $1 \%$, es krim $0,5 \%$, untuk sayur yang dikalengkan yang mengandung mentega atau minyak lemak, baik secara tunggal atau campuran sebesar
1\% b/b (Anonymous, 1986). K-karaginan jugá digunakan sebagai bahan stabilisator produk susu dan roti karena kemampuannya membentuk komplek stabil antara tepung dan protein susu (Guiseley et al., 1980). Penggunaan $k$ - karaginan dalam pengolahan fish meat loaf dalam konsentrasi tertentu diharapkan dapat memperbaiki dan mempertahankan stabilitas sistem emulsi, karena adanya sifat hidrofilik dari gugus ester sulfat yang mampu mengikat air.

Teknik ekstraksi $k$-karaginan dari rumput laut telah berhasil dikembangkan oleh Pusat Riset Penelitian Produk dan Sosial Ekonomi Kelautan dan Perikanan, tetapi penelitian pemanfaatannya belum banyak dilakukan. Dalam penelitian ini dipelajari pemanfaatan $k$ karaginan hasil ekstraksi rumput laut Eucheuma cottonii sebagai penstabil dalam pembuatan fish meat loaf. Penelitian ini bertujuan untuk mempelajari aspek $k$ karaginan sebagai bahan penstabil serta pengaruhnya terhadap kualitas mutu fish meat loaf serta daya awet produk selama penyimpanan.

\section{BAHAN DAN METODE}

\section{Bahan}

Bahan yang digunakan dalam penelitian ini adalah ikan tongkol (Euthyinnus pelamys. $L$ ) segar yang diperoleh dari TPI Muara Angke Jakarta. Ikan dibawa ke Pusat Riset Pengolahan Produk dan Sosial Ekonomi Kelautan dan Perikanan (PRPPSE) dengan menggunakan es di dalam cool box. Ikan disiangi dan dipisahkan dagingnya. Sedangkan $k$-karaginan yang digunakan sebagai bahan penstabil diekstraksi dari rumput laut Eucheuma cottonii dengan metode seperti yang telah diuraikan oleh Wibowo, et al. (1993)

\section{Pembuatan Fish Meat Loaf}

Fish meat loaf dibuat dari campuran daging ikan tongkol, lemak sapi, dan bumbu-bumbu seperti yang diuraikan Daulay (1984) dengan komposisi sebagai berikut: Daging tongkol $55 \%$, lemak sapi $20 \%$, garam $2 \%$, lada putih $0,4 \%$, bawang merah $4 \%$, bawang puth $1,5 \%$, gula pasir $0,8 \%$, monosodium glutamat $0,3 \%$ dan tepung terigu $16 \%$. Diagram alir proses pembuatan fish meat loaf disajikan pada Gambar 1. 


\section{Metode Penelitian}

Penelitian ini dilakukan dengan menggunakan variabel sebagai berikut :

A. Konsentrasi bahan penstabil tepung $k$ karaginan yang digunakan adalah $0 \%$ (kontrol); $0,25 \%, 0,50 \%, 0,75 \%$ dan $1 \%$ (b/b).

B. Lama waktu penyimpanan : $0,15,30,45$ dan 60 hari, dilakukan pada suhu kamar.

Penelitian dilaksanakan dengan menggunakan rancangan petak terbagi (split plot

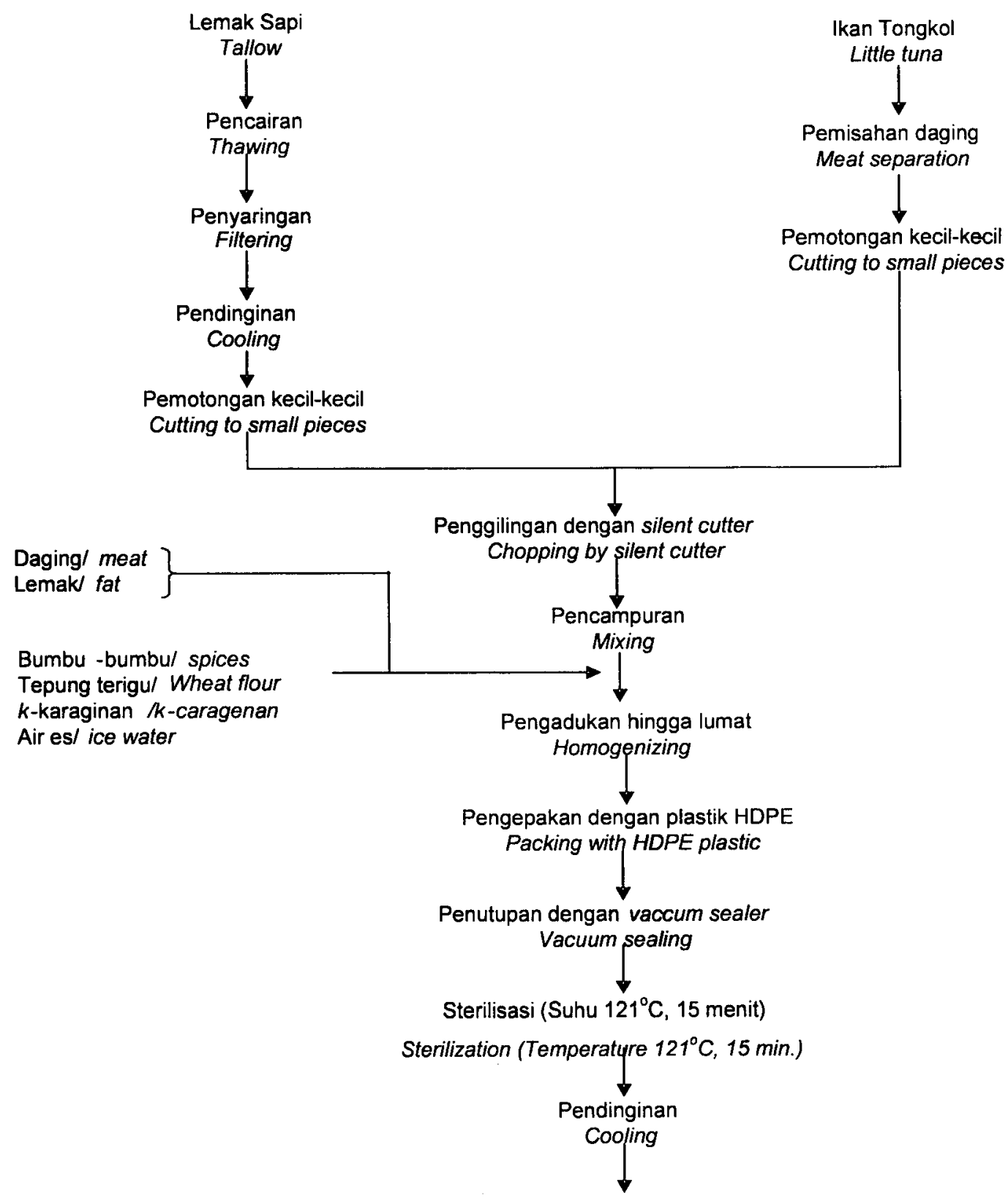

design) dengan 2 kali ulangan.

\section{Pengamatan}

Pengamatan yang dilakukan terhadap fish meat loaf adalah protein larut garam (Christiansen and Saffle, 1967), daya ikat air (Wierbichi and Deathrage, 1958), aktivitas emulsi dan stabilitas emulsi (Sathe and Salunke, 1981), jumlah bakteri total dengan menggunakan metode tuang, uji preferensi organoleptik terhadap warna, bau, rasa, dan tekstur dengan menggunakan skala Hedonik 1-9, serta analisis komposisi proksimat fish

Fish Meat Loaf

Gambar 1. Diagram alir proses pengolahan fish meat loaf Figure 1. Flow chart of fish meat loaf processing 
meat loaf pada awal dan akhir penyimpanan.

\section{HASIL DAN PEMBAHASAN}

\section{Komposisi Proksimat Produk}

Hasil analisis komposisi proksimat fish meat loaf yang dilakukan pada awal dan akhir penyimpanan disajikan pada Tabel 1 . menyebabkan produk fish meat loaf yang ditambah dengan $k$-karaginan mempunyai nilai protein larut garam yang lebih tinggi dibandingkan dengan kontrol.

Hasil analisis ragam menunjukkan bahwa protein larut garam fish meat loaf dengan penambahan $k$-karaginan berbeda sangat nyata $(p<0.01)$ dengan protein larut garam fish

Tabel 1 : Hasil analisis proksimat fish meat loaf pada awal dan akhir penyimpananan

Table 1 : Result of proximate analysis of fish meat loaf at the beginning and end of storage

\begin{tabular}{|c|c|c|c|c|c|c|c|c|}
\hline \multirow[t]{2}{*}{$\begin{array}{c}\text { Kons } \\
\text { Karaginan } \\
\text { Carrageenan } \\
\text { Conc. }\end{array}$} & \multicolumn{2}{|c|}{$\begin{array}{l}\text { Kadar air (bb) } \\
\text { Water content } \\
\text { (wb) }\end{array}$} & \multicolumn{2}{|c|}{$\begin{array}{l}\text { Kadar protein (bk) } \\
\text { Protein content } \\
\text { (db) }\end{array}$} & \multicolumn{2}{|c|}{$\begin{array}{l}\text { Kadar lemak (bk) } \\
\text { Fat Content (db) }\end{array}$} & \multicolumn{2}{|c|}{$\begin{array}{c}\text { Kadar abu (bk) } \\
\text { Ash content } \\
\text { (db) }\end{array}$} \\
\hline & $\begin{array}{l}\text { Awal } \\
\text { Begin } \\
\text { ning }\end{array}$ & $\begin{array}{l}\text { Akhir } \\
\text { End of } \\
\text { storage }\end{array}$ & $\begin{array}{l}\text { Awal } \\
\text { Begin } \\
\text { ning }\end{array}$ & $\begin{array}{l}\text { Akhir } \\
\text { End of } \\
\text { storage }\end{array}$ & $\begin{array}{l}\text { Awal } \\
\text { Begin } \\
\text { ning }\end{array}$ & $\begin{array}{l}\text { Akhir } \\
\text { End of } \\
\text { storage }\end{array}$ & $\begin{array}{l}\text { Awal } \\
\text { Begin } \\
\text { ning }\end{array}$ & $\begin{array}{l}\text { Akhir } \\
\text { End of } \\
\text { storage }\end{array}$ \\
\hline Kontrol & 53.70 & 52.85 & 23.74 & 15.25 & 28.08 & 23.79 & 4.03 & 3.89 \\
\hline $0,25 \%$ & 54.84 & 55.46 & 28.80 & 18.84 & 27.93 & 25.80 & 5.48 & 5.45 \\
\hline $0,50 \%$ & 57.51 & 55.20 & 27.66 & 18.44 & 25.59 & 23.21 & 8.33 & 7.44 \\
\hline $0,75 \%$ & 55.95 & 56.03 & 30.64 & 16.54 & 24.21 & 24.04 & 8.57 & 8.17 \\
\hline $1.0 \%$ & 56.75 & 56.30 & 27.75 & 19.67 & 19.61 & 24.33 & 7.27 & 6.88 \\
\hline
\end{tabular}

\section{Pengaruh K-karaginan Terhadap Sifat Emulsi Produk}

Untuk mempelajari pengaruh $k$-karaginan terhadap sifat emulsi fish meat loaf, maka pengamatan dilakukan terhadap protein larut garam, daya ikat air, aktivitas emulsi dan stabilitas emulsinya.

\section{Protein larut garam}

Protein larut garam adalah kelompok protein serabut otot yang terdiri atas aktin dan miosin serta aktomiosin yang merupakan ikatan antara aktin dan miosin yang berperan dalam pembentukan emulsi.

Nilai rata-rata protein larut garam fish meat loaf dengan berbagai konsentrasi k-karaginan selama penyimpanan dapat dilihat pada Gambar 2. Semakin tinggi konsentrasi kkaraginan yang digunakan semakin besar pula nilai protein larut garamnya.

Penambahan k-karaginan, menyebabkan terjadinya interaksi gugus sulfat yang bermuatan negatif dan gugus amino yang bermuatan positif, sehingga terbentuk ikatan intramolekuler di antara gugus-gugus tersebut yang membentuk suatu kesatuan yang tidak mudah larut (Niwa, 1992). Reaktivitas kkaraginan dengan gugus amino (protein) ini meat loaf tanpa penambahan karaginan. Uji Tukey antar penggunaan konsentrasi $k$ karaginan menunjukkan perbedaan yang nyata antara fish meat loaf tanpa penambahan $k$-karaginan dengan penggunaan $k$-karaginan pada taraf 0,5 dan $1 \%$.

Selama penyimpanan produk, nilai protein larut garam cenderung menurun dan penurunan secara nyata terjadi setelah 30 hari penyimpanan. Hal ini sejalan dengan meningkatnya jumlah bakteri, terutama bakteri proteolitik yang dapat merusak protein sehingga menyebabkan berkurangnya protein larut garam selama penyimpanan. Penyimpanan selama 45 dan 60 hari menyebabkan turunnya kadar protein larut garam yang berbeda nyata $(P<0,01)$ dengan produk yang disimpan selama 15 dan 30 hari.

\section{Daya ikat air}

Daya ikat air merupakan banyaknya air yang dikeluarkan oleh daging, jika diberi beban/tekanan tertentu. Daya ikat air yang didapat merupakan daya ikat air relatif yang dinyatakan sebagai luasan resapan air pada kertas saring per satuan waktu. Nilai rata-rata daya ikat air produk pada penggunaan berbagai konsentrasi k-karaginan selama penyimpanan dapat dilihat pada Gambar 3 . 


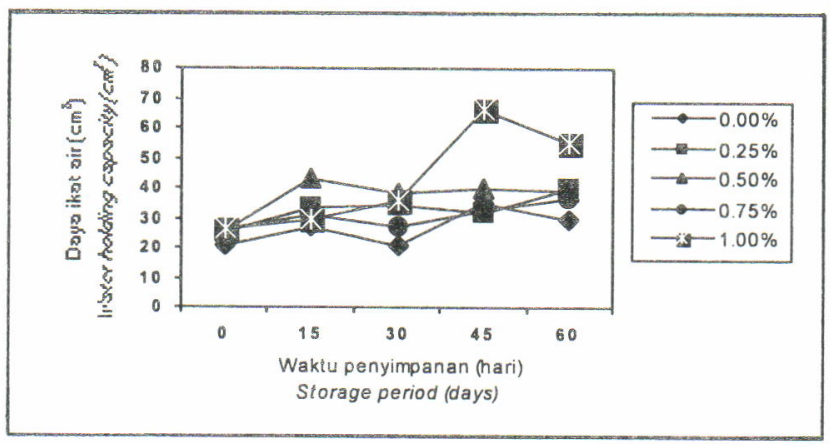

Gambar 2. Kadar Protein larut garam (\%,bk) fish meat loaf pada berbagai konsentrasi $k$ karaginan dan lama waktu penyimpanan

Figure 2. Salt soluble protein content $(\%, d b)$ fish meat loaf at various k-carrageenan concentration levels and storage period

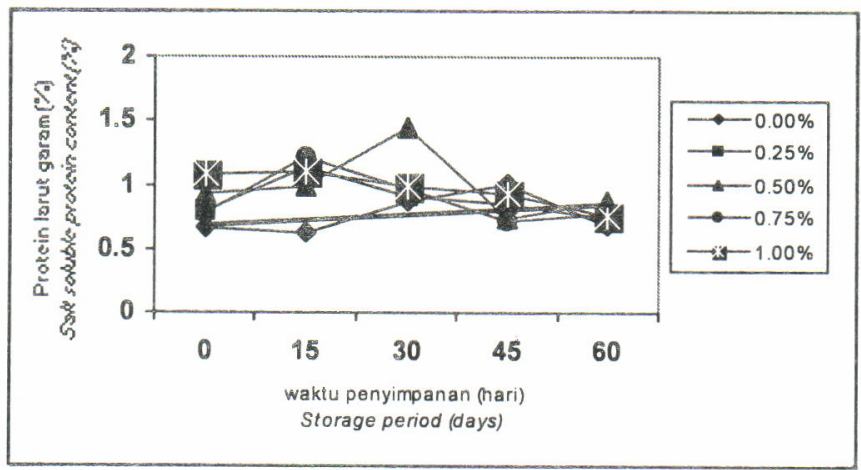

Gambar 3. Daya ikat air $\left(\mathrm{cm}^{2}\right)$ fish meat loaf pada berbagai konsentrasi $k$-karaginan dan masa penyimpanan.

Figure 3. Water holding capacity of fish meat loaf at various k-carrageenan concentration levels and storage period

Daya ikat air fish meat loaf yang diolah menggunakan k-karaginan lebih tinggi bila dibandingkan dengan kontrol. Daya ikat air pada produk yang diolah tanpa penambahan k-karaginan (kontrol) sebesar $20,83 \%$, naik menjadi $26,67 \%$ jika konsentrasi $k$-karaginan yang ditambahkan sebesar $0,75 \%$. Pada saat pengolahan fish meat loaf adanya perlakuan fisik seperti pelumatan akan menyebabkan terbentuknya ikatan kimia antara protein miofibril yang berperan untuk membentuk struktur jaringan tiga demensi (Foegeding et al, 1996; Suparno, 1998). Penambahan $k$ karaginan dalam pengolahan fish meat loaf akan menyebabkan jaringan tiga dimensi yang dibangun mampu memerangkap air.

Hal ini disebabkan karena k-karaginan merupakan senyawa polisakarida yang mudah mengikat air dengan adanya gugus sulfat pada rantai molekulnya yang bersifat hidrofilik. Ikatan tersebut bersifat irreversible, artinya air tersebut akan mudah dilepaskan kembali (Chapman and Chapman, 1980). Kondisi ini akan menyebabkan semakin tinggi konsentrasi $k$-karaginan yang ditambahkan semakin banyak air yang terikat dan pada saat diberi beban atau tekanan, air tersebut akan dilepaskan, sehingga menghasilkan nilai daya ikat air yang tinggi. Hasil analisis ragam menunjukkan bahwa penambahan $k$ karaginan menyebabkan kenaikan daya ikat air yang berbeda sangat nyata $(P<0,01)$ dengan produk yang diolah tanpa penambahan $k$-karaginan (kontrol). Uji Tukey antar penggunaan konsentrasi k-karaginan menunjukkan perbedaan yang nyata $(P=0,01)$ antara konsentrasi $0 \%$ dengan 0,5 dan $1 \%$. Demikian juga semakin lama waktu penyimpanan semakin besar pula nilai daya ikat airnya. Nilai daya ikat air pada awal penyimpanan berbeda nyata $(P=0,01)$ dengan nilai daya ikat air pada fish meat loaf yang telah disimpan selama $15,30,45$ dan 60 hari.

\section{Aktivitas emulsi}

Aktivitas emulsi menunjukkan emulsi yang 
dapat dibentuk oleh setiap volume air dan minyak yang ditambahkan. Pengaruh penggunaan $k$-karaginan pada berbagai konsentrasi terhadap aktivitas emulsi fish meat loaf selama penyimpanan dapat dilihat pada Gambar 4. semakin kecil ukuran partikel semakin luas permukaannya sehingga semakin besar pula aktivitas emulsinya.

Hasil analisis ragam menunjukkan bahwa fish meat loaf yang diolah dengan

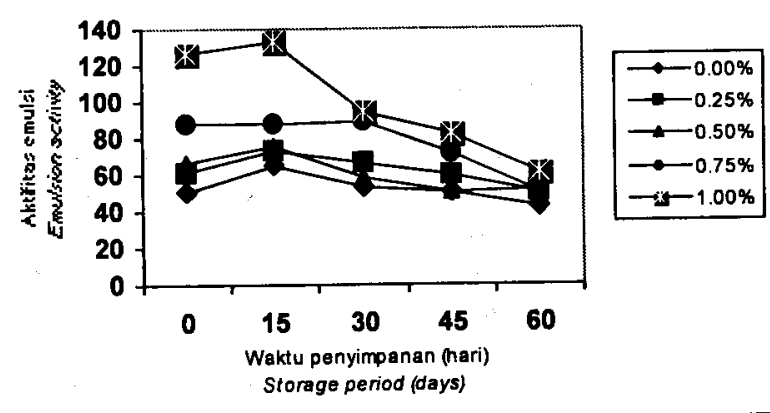

Gambar 4. Aktivitas emulsi fish meat loaf pada berbagai konsentrasi k-karaginan selama penyimpanan.

Figure 4. Emulsion activity of fish meat loaf at various $k$-carrageenan concentration levels and storage period

Aktivitas emulsi produk semakin meningkat dengan semakin meningkatnya konsentrasi $k$ karaginan yang ditambahkan. $\mathrm{Hal}$ ini disebabkan secara alamiah k-karaginan mempunyai gugus hidrofilik (gugus sulfat) dan hidrofobik (3, 6-Anhydrogalaktosa) sehingga dapat berperan sebagai emulsifier. Perannya sebagai emulsifier ini akan menyebabkan meningkatnya aktivitas emulsi sehingga semakin banyak minyak yang terdispersi dalam air. Gugus sulfat pada k-karaginan yang bersifat hidrofilik akan mengasorbsi air sehingga tegangan permukaan antara kedua fase yang membentuk emulsi menurun. Menurunnya tegangan permukaan tersebut akan mempermudah pembentukan suatu matrik dimana globula-globula lemak yang terdipersi akan diselubungi oleh protein dan air. (Fashier and Parker, 1985). Aktivitas emulsi ini selain dipengaruhi oleh emulsifier juga dipengaruhi oleh ukuran partikel yaitu penambahan $k$-karaginan berbeda sangat nyata $(P<0.01)$ dengan kontrol. Uji Tukey menunjukkan bahwa penambahan $k$ karaginan 0,75 dan $1 \%$ menyebabkan peningkatan aktivitas emulsi sehingga berbeda dengan kontrol. Penyimpanan menyebabkan menurunnya aktivitas emulsi, yang terjadi setelah 30 hari penyimpanan.

Penurunan ini dapat dikaitkan dengan terdegradasinya protein miofibril yang berperan dalam pembentukan emulsi oleh bakteri proteolitik yang menyebabkan berkurangnya aktivitas emulsi (Winarno, 1991).

\section{Stabilitas emulsi}

Stabilitas emulsi merupakan kemampuan protein untuk mempertahankan sistem emulsi terhadap perlakuan panas. Nilai rata-rata stabilitas emulsi pada berbagai konsentrasi

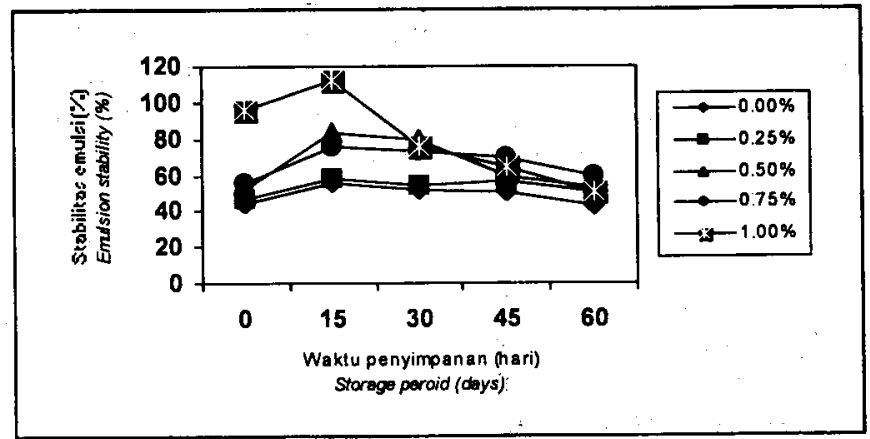

Gambar 5. Stabilitas emulsi $(\%, b k)$ fish meat loaf pada berbagai konsentrasi $k$-karaginan

Figure 5. Emulsion stability $(\%, b k)$ of fish meat loaf at various $k$-carrageenan concentration levels and storage period 
penambahan $k$-karaginan dan waktu penyimpanan dapat dilihat pada Gambar 5.

Semakin tinggi konsentrasi k-karaginan yang digunakan sebagai bahan penstabil, nilai stabilitas emulsi produk semakin meningkat. Penambahan $k$-karaginan dapat dikaitkan dengan peran $k$-karaginan sebagai stabilizer (Sanderson, 1981). Dalam hal ini penambahan $k$-karaginan akan menyebabkan gugus hidrofilik menyerap air sehingga mampu meningkatkan viskositas fase kontinyu yang mengakibatkan protein miofibril yang membentuk suatu matrik yang menyelubungi globula lemak menjadi kokoh, yang akhirnya meningkatkkan stabilitas emulsinya. Semakin tinggi stabilitas suatu sistem emulsi akan semakin tahan terhadap panas yang diberikan selama pengolahan (Lanier, 1994).

Hasil analisis ragam menunjukkan bahwa stabilitas emulsi fish meat loaf dengan penambahan $k$-karaginan berbeda sangat nyata $(P, 0,01)$ dengan kontrol. Uji Tukey menunjukkan bahwa penambahan kkaraginan 0,5 sampai $1 \%$ berbeda sangat nyata dengan kontrol. Selama 30 hari penyimpanan terjadi kenaikan stabilitas emulsi tetapi setelah 45 hari penyimpanan terjadi penurunan stabilitas emulsi yang

\section{Pengaruh K-karaginan terhadap $\mathrm{pH}$ dan jumlah bakteri total}

Selama penyimpanan, dilakukan pengamatan terhadap nilai $\mathrm{pH}$ dan kandungan jumlah bakteri total.

Nilai rata-rata $\mathrm{pH}$ produk pada berbagai konsentrasi penambahan $k$-karaginan dan waktu penyimpanan dapat dilihat pada Gambar 6.

Penggunaan k-karaginan menyebabkan kenaikan nilai $\mathrm{pH}$ dibandingkan dengan kontrol. Ini disebabkan karena karaginan mempunyai $\mathrm{pH}$ yang bersifat netral (7) dibandingkan dengan daging tongkolnya sendiri yang mempunyai $\mathrm{pH} 5,79$. Nilai $\mathrm{pH}$ produk fish meat loaf berkisar antara 5,546,05 . Nilai $\mathrm{pH}$ ini tidak berbeda jauh dengan nilai $\mathrm{pH}$ produk sejenis sosis yang berkisar antara 5-6 (Lanier, 1994). Dengan demikian penambahan $k$-karaginan dengan konsentrasi yang lebih tinggi akan menyebabkan nilai $\mathrm{pH}$ naik dan akan menghambat proses emulsi. Hal ini karena kemampuan fish meat loaf membentuk emulsi maksimum pada $\mathrm{pH} 5,2$ (Swift and Sulzbacher di dalam Suwarsono, 1987).

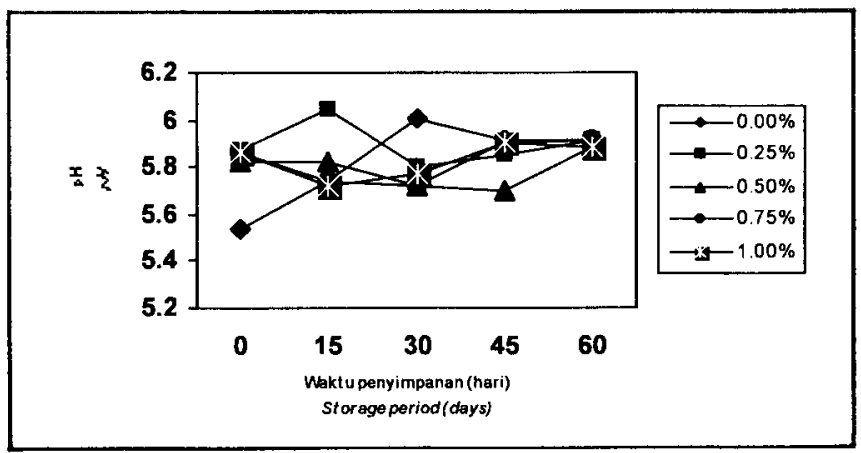

Gambar 6. Nilai $\mathrm{pH}$ fish meat loaf pada berbagai konsentrasi $k$-karaginan dan lama waktu penyimpanan.

Figure 6. $\mathrm{pH}$ of fish meat loaf at various $k$-carrageenan concentration levels and storage period

cukup tajam. Hal ini dapat dikaitkan dengan terjadinya proses sineresis pada gel $k$ karaginan yang menyebabkan bebasnya air yang terikat menjadi air bebas, (Glicksman, 1983), sehingga akan menurunkan viskositas fase kontinyu dan menyebabkan stabilitas emulsi menurun. Disamping itu juga dapat disebabkan oleh rusaknya protein miofibril sebagai penyusun sistem emulsi oleh aktivitas mikroba selama penyimpanan.
Hasil analisis ragam menunjukkan bahwa penambahan $k$-karaginan terhadap procuk menyebabkan kenaikan $\mathrm{pH}$ yang cukup nyata dibandingkan dengan kontrol. Nilai pH produk selama penyimpanan berfluktuasi dengan kecenderungan meningkat. Peningkatan di duga disebabkan oleh terbentuknya senyawa basa yang mudah menguap akibat degradasi protein. 
Dari hasil pengamatan nilai logaritma jumlah bakteri total fish meat loaf pada berbagai konsentrasi k-karaginan dan lama waktu penyimpanan disajikan pada Gambar 7 . Hasil analisis menunjukkan bahwa meskipun dalam proses pembuatan fish meat loaf dilakukan proses sterilisasi tetapi waktu atau suhu yang digunakan tidak cukup untuk membunuh bakteri yang terlihat dari kandungan jumlah bakteri pada awal pengamatan yang masih cukup tinggi yaitu $2.51 \mathrm{x}$ $10^{2}$.

Hasil analisis ragam menunjukkan bahwa penggunaan $k$-karaginan pada pengolahan fish meat loaf tidak memberikan pengaruh yang nyata terhadap kandungan jumlah bakteri produk. Lama penyimpanan menyebabkan terjadinya peningkatan jumlah bakteri total secara nyata. Kandungan bakteri pada awal penyimpanan berkisar antara $2.51 \times 10^{2}$. $1.25 \times 10^{3}$. Namun demikian nilai ini masih lebih rendah dari batas aman jumlah bakteri suatu produk untuk dikonsumsi yaitu $10^{5}-10^{8}$ (Jay, 1978). Pada penyimpanan produk selama 30 hari kandungan jumlah bakterinya relatif tetap. Jumlah bakteri mulai meningkat setelah produk disimpan selama 45 hari. Pada akhir masa penyimpanan terjadi kenaikan jumlah bakteri yang cukup nyata pada produk yang diolah tanpa penambahan $k$-karaginan (kontrol) tetapi jumlahnya tidak melebihi batas yang tidak aman untuk dikonsumsi.

\section{Uji Organoleptik}

Uji organoleptik terhadap produk fish meat loaf meliputi rupa, warna, bau, rasa, dan tekstur dilakukan dengan menggunakan uji kesukaan dengan menggunakan skala Hedonik 1-9. Hasil pengamatan menunjukkan bahwa penambahan $k$-karaginan sampai pada konsentrasi $0,75 \%$ tidak memberikan pengaruh yang nyata terhadap nilai rupa produk. Penambahan $k$-karaginan sampai $1 \%$ berpengaruh terhadap menurunnya rupa produk, yaitu menjadi kurang cemerlang yang berbeda dengan kontrol. Pényimpanan menyebabkan perubahan yang sangat nyata $(P, 0.01)$ terhadap nilai rupa produk dan penyimpanan selama 15 hari sudah menyebabkan menurunnya nilai rupa.

Pengamatan terhadap warna menunjukkan bahwa penambahan $k$-karaginan dalam pengolahan fish meat loaf memberikan pengaruh yang sangat nyata $(P<0.01)$ terhadap warna produk yang dihasilkan. Penambahan $k$-karaginan menyebabkan warna fish meat loaf yang dihasilkan lebih menarik, cerah dan cemerlang bila dibandingkan dengan kontrol. Secara alami fish meat loaf berwarna coklat cerah yang merupakan warna kombinasi antara asam amino dengan karbohidrat seperti glukosa dan ribosa pada daging ikan (Borgstrom, 1969). Penyimpanan menyebabkan warna produk semakin menurun yaitu menjadi kusam dan tidak cemerlang.

Penambahan $k$-karaginan

pada konsentrasi 0.75 dan $1 \%$ menghasilkan bau fish meat loaf yang lebih harum dibandingkan dengan kontrol. Seperti telah diuraikan di muka bahwa penambahan $k$-karaginan dapat mempertahankan protein baik yang larut garam maupun air. Kandungan protein yang cukup tinggi ini menyebabkan bau fish meat loaf yang dihasilkan lebih harum, sedangkan penyimpanan menyebabkan menurunnya protein, sehingga bau yang dihasilkan menjadi kurang harum.

Hasil uji rasa menunjukkan bahwa penggunaan $k$-karaginan tidak memberikan pengaruh yang nyata terhadap nilai rasa produk yang dihasilkan. Sedangkan lama

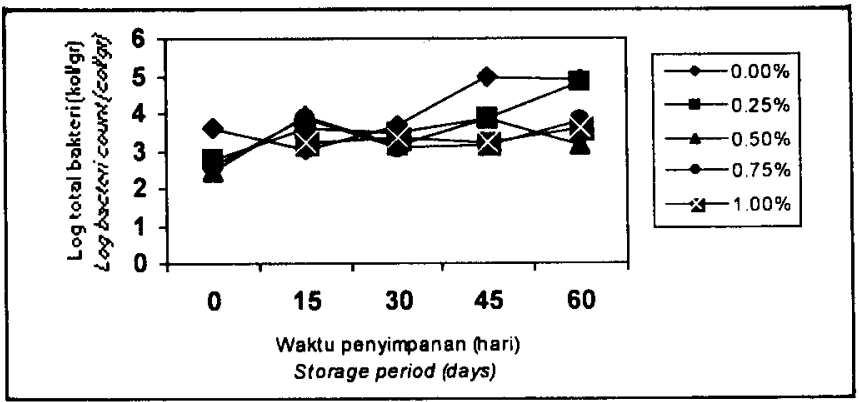

Gambar 7. Logaritma jumlah bakteri total fish meat loaf pada berbagai konsentrasi karaginan dan waktu penyimpanan.

Figure 7. Log bacteri count of fish meat loaf at various $k$-carrageenan concentration levels and storage period. 
penyimpanan memberikan pengaruh yang nyata. Cita rasa makanan dipengaruhi oleh komponen-komponen yang terdapat di dalam makanan seperti protein, lemak dan kabohidrat yang menyusunnya. Komponen pembentuk cita rasa tersebut akan mengalami degradasi sejalan dengan lamanya waktu penyimpanan sehingga menyebabkan menurunnya penilaian cita rasa oleh panelis.

Pengamatan terhadap tekstur menunjukkan bahwa penggunaan k-karaginan sampai konsentrasi $0.75 \%$ tidak berbeda dengan kontrol. Penambahan k-karagianan dengan konsentrasi $1 \%$ memberikan pengaruh terhadap turunnya nilai kesukaan panelis terhadap tekstur fish meat loaf yang dihasilkan. Sedangkan lama penyimpanan menyebabkan nilai tekstur sedikit menurun.

\section{KESIMPULAN} bahwa :

Dari penelitian ini dapat disimpulkan

1. Penambahan k-karaginan dalam pengolahan fish meat loaf memberikan pengaruh terhadap meningkatnya nilai protein larut garam, daya ikat air, aktivitas emulsi, dan stabilitas emulsi. Sedangkan lama penyimpanan berpengaruh nyata terhadap menurunnya sifat emulsi produk.

2. Penggunaan $k$-karaginan $1 \%$ menghasilkan sifat emulsi produk yang meliputi protein larut garam, daya ikat air, aktivitas emulsi dan stabilitas emulsi terbaik dibandingkan dengan konsentrasi $k$-karaginan lainnya. Namun jika dihubungkan dengan stabilitas emulsi selama penyimpanan maka penggunaan $k$-karaginan $0.75 \%$ lebih disarankan.

3. Penggunaan k-karaginan dengan konsentrasi $0,75 \%$ dan $1 \%$ menghasilkan sifat emulsi produk yang berbeda dengan kontrol selama penyimpanan. Sifat emulsi produk mampu bertahan selama 30 hari, namun setelah 30 hari penyimpanan terjadi penurunan yang cukup cepat terhadap semua parameter yang diamati. Produk yang diolah tanpa $k$-karaginan penurunannya lebih tajam dibandingkan dengan yang diolah dengan penambahan karaginan.

4. Penambahan k-karaginan hanya berpengaruh nyata terhadap warna dan bau produk. Penggunaan k-karaginan $0.75 \%$ menghasilkan rasa bau dan tekstur yang lebih dapat diterima oleh panelis. Oleh karena itu disarankan bahwa penggunaan $k$-karaginan sebagai bahan penstabil dalam pembuatan fish meat loaf sebaiknya pada konsentrasi tidak lebih dari $0,75 \%$.

\section{DAFTAR PUSTAKA}

Anonymous, 1986. Marine Colloids Aplication Bulletin. FMC. Cooporation. Philadephia USA. 7 $p$

Borgstrom, G., 1969. Fish as Food, Vol I. AP Press. New York, 372p

Chapman, V.J. and Chapman, D.J. 1980. Seaweed and Their Uses. Chapman and Hall. London $333 \mathrm{p}$.

Christiansen, J.A. and Saffle, R.L. 1967. Plant and animal fats and oils emulsified in a model system with muscle salt soluble protein. J. Food Technol. 21:1024-1027.

Daulay, D. 1984. Penggunaan Starchy Materials Sebagai Binder pada Pembuatan Fish Meat Loaf. Fak Teknologi Pertanian, IPB Bogor. 56 p.

Fashier, L.R. and Parker, N.S. (1985). How Do Food Emulsion Stabilizers Work?. CRISRO Food Research Quarterley. 45 (2): 33-39.

Foegeding, E.A. and Lanier, T.C. 1996. Characteristics of Edible Muscle Tissues In Fenema, O.R. (ed.). Food Chemistry II. Marcel Dekker Inc. New York pp : 901- 907.

Glicksman, M. 1983. Food Hydrocolloids. Vol II. CRC. Press Inc, Florida. 199 p.

Guiseley, K.B., Stanley, N.F. and Whitehouse, F.A. 1980. Carrageenan. In Davidson, R.L. (ed). Handbook of Water Soluble Gums and Resin. Mc Grow Hill Book Company. N.Y. Toronto. London. p. 5-30

Jay, J.M. 1978. Modern Food Microbiology. $2^{\text {nd }}$ Edition. Van Nostrand Comp. N.Y. Toronto. London. $219 \mathrm{p}$.

Lanier, T.C. 1994. Fungtional food protein ingredients from fish. In Sikorski, Z.E., Pan, B.S. and Shahidi, F. (eds.) Seafood Proteins. Chapman \& Hall, New York London. p. 132148.

Moirano, T.W. 1977. Sulphated seaweed polysaccharides. In Food Colloids. The AVI Publishing. West Port. Connecticut. p. 347-381

Niwa, E. 1992. Chemistry of surimi gelation In Lannier, Tyre, C. and Lee Chong M. (eds.) Surimi Technology, Marcel Decker, Inc. pp.322.

Sanderson, G.R. 1981. Phylosaccharides in Foods. Food Technology. 35 (7):50-57.

Suparno, 1998. Ilmu dan Teknologi Daging. Gajahmada University Press. Yogyakarta p. 13. 
Suwasono, S. 1987. Pemucatan Daging Merah Ikan Tongkol Untuk Pembuatan Fish Meat Loaf. Fakultas Teknologi Pertanian, IPB. Bogor. 66 p.

Sathe, S.K. and Salunkhe, D.K. 1981. Functional Properties of Great Nothern Bean (Phaseolus vulgaris, L.) Proteins. J. Food Sci. 46(1): 71-74.

Wierbicki, E. and Deatherage, F.E. 1958. Determination of water holding capacity of fresh water. J. of Agriculture and Food Chemistry (6):
387-392.

Wibowo, S., Suryaningrum, T.D., Suparno, Nasran, S., Setiabudi, E., Murtini, J.T., Jamal, B., Retnowati, N. dan Saleh, M. 1993. Teknologi Penanganan dan Pengolahan Rumput Laut. Sub Balai Penelitian Perikanan Laut Slipi Jakarta. p. 7-10

Winarno, F.G. 1991. Kimia Pangan dan Gizi. PT Gramedia. Jakarta 253 p. 
Lampiran 1. Nilai rata-rata organoleptik fish meat loaf pada berbagai konsentrasi karagianan dan lama penyimpanan.

Appendix 1. Organoleptic score of Fish meat loaf at various carrageenan concentraion and storage period

\begin{tabular}{|c|c|c|c|c|c|c|}
\hline \multirow[t]{2}{*}{ Parameter } & \multirow[t]{2}{*}{ Kons.Karaginan } & \multicolumn{5}{|c|}{ Lama Penyimpanan (stored period) } \\
\hline & & 0 & 15 & 30 & 45 & 60 \\
\hline Rupa & $0.0 \%$ & 7.0 & 6.5 & 6.2 & 6.3 & 5.1 \\
\hline \multirow[t]{4}{*}{ (appearance) } & $0.25 \%$ & 7.0 & 6.4 & 6.4 & 5.5 & 6.1 \\
\hline & $0.5 \%$ & 7.0 & 5.9 & 5.8 & 6.0 & 5.6 \\
\hline & $0.75 \%$ & 7.0 & 6.6 & 6.3 & 6.4 & 6.2 \\
\hline & $1.0 \%$ & 6.4 & 5.9 & 6.3 & 6.2 & 6.0 \\
\hline Warna & $0.0 \%$ & 6.7 & 6.5 & 6.8 & 6.8 & 6.5 \\
\hline \multirow[t]{4}{*}{ (color) } & $0.25 \%$ & 6.8 & 6.1 & 5.8 & 6.0 & 5.6 \\
\hline & $0.5 \%$ & 6.9 & 6.0 & 5.9 & 6.5 & 5.6 \\
\hline & $0.75 \%$ & 6.3 & 5.8 & 6.1 & 6.1 & 4.9 \\
\hline & $1.0 \%$ & 6.8 & 5.6 & 5.6 & 6.1 & 6.1 \\
\hline Bau & $0.0 \%$ & 6.7 & 6.4 & 6.1 & 5.9 & 5.3 \\
\hline \multirow[t]{4}{*}{ (odor) } & $0.25 \%$ & 6.7 & 5.9 & 5.8 & 6.0 & 5.0 \\
\hline & $0.5 \%$ & 6.7 & 6.2 & 6.3 & 5.8 & 5.3 \\
\hline & $0.75 \%$ & 6.8 & 6.2 & 6.3 & 5.8 & 5.3 \\
\hline & $1.0 \%$ & 6.9 & 6.6 & 6.4 & 6.2 & 5.9 \\
\hline Rasa & $0.0 \%$ & 6.8 & 6.6 & 5.7 & 5.3 & 4.9 \\
\hline \multirow[t]{4}{*}{ (taste) } & $0.25 \%$ & 6.8 & 6.1 & 5.6 & 5.3 & 5.7 \\
\hline & $0.5 \%$ & 6.5 & 6.4 & 5.8 & 5.8 & 5.6 \\
\hline & $0.75 \%$ & 6.9 & 7.0 & 5.8 & 5.4 & 5.1 \\
\hline & $1.0 \%$ & 6.6 & 6.5 & 5.5 & 5.1 & 5.4 \\
\hline \multirow{5}{*}{$\begin{array}{l}\text { Tekstur } \\
\text { (texture) }\end{array}$} & $0.0 \%$ & 7.0 & 6.5 & 7.4 & 6.3 & 5.9 \\
\hline & $0.25 \%$ & 7.0 & 6.4 & 6.4 & 6.4 & 6.1 \\
\hline & $0.5 \%$ & 7.0 & 6.4 & 6.3 & 6.4 & 6.2 \\
\hline & $0.75 \%$ & 6.9 & 6.7 & 6.6 & 6.6 & 6.4 \\
\hline & $1.0 \%$ & 6.6 & 6.1 & 6.6 & 6.4 & 6.3 \\
\hline
\end{tabular}


